\title{
EVALUASI DESENTRALISASI, SENTRALISASI, DAN ZONING PELAKSANAAN AUDIT TERHADAP EFISIENSI BIAYA PERJALANAN DINAS AUDIT KEPABEANAN DAN CUKAI
}

\author{
Ario Seno Nugroho'), Muhamad Fachrudin ${ }^{2)}$ \\ 1. Jurusan Bea dan Cukai, Politeknik Keuangan Negara STAN, \\ Jalan Bintaro Utama Sektor V Bintaro Jaya, Tangerang Selatan 15222. \\ 2. Jurusan Bea dan Cukai, Politeknik Keuangan Negara STAN, \\ Jalan Bintaro Utama Sektor V Bintaro Jaya, Tangerang Selatan 15222. \\ E-mail: ario_sn@pknstan.ac.id
}

\section{INFORMASI ARTIKEL}

Tanggal masuk

[2020-03-18]

Revisi

[2020-05-11]

Tanggal terima

[2020-06-20]

\begin{abstract}
:
Organization structure is an important factor in determining organization's achievement of its objectives. The Directorate of Audit on Customs and Excise' objective is to conduct compliance audit on entities practicing import, export and excise matters. The directorate has been implemented three types of organization structure: centralization, decentralization, and zoning, where each type by nature having its advantages and drawbacks. This study simulates quantitative data by using descriptive quantitative approach to determine the most ideal organizational structure of the directorate in terms of cost efficiency. The simulation method being used is linear program adjusted by several constrains in transportation cost. The simulation is conducted by using solver program provided in Ms Excel. The results show that decentralization is the most efficient organization type in terms of cost efficiency, followed by zoning, and centralization.
\end{abstract}

Keywords: centralization, decentralization, zoning, linear programming, transportation problem.

\begin{abstract}
ABSTRAK:
Bentuk organisasi dapat menentukan keberhasilan organisasi dalam memenuhi tujuan. Direktorat Audit Kepabeanan dan Cukai (Dit AKC), memiliki tujuan untuk melakukan audit kepada perusahaan yang melakukan impor, ekspor, dan cukai. Terdapat tiga bentuk organisasi yang telah digunakan oleh Dit AKC, yaitu: sentralisasi, desentralisasi, dan zoning. Setiap bentuk organisasi memiliki kelebihan dan kekurangan. Penelitian ini menggunakan pendekatan deskriptif kuantitatif dalam bentuk simulasi dan bertujuan mencari bentuk organisasi yang ideal untuk Dit AKC dari sisi efisiensi biaya. Metode simulasi yang digunakan adalah program linier, masalah transportasi. Penelitian ini menggunakan solver di Microsoft Excel. Hasil dari penelitian ini menunjukkan bentuk organisasi desentralisasi memberikan hasil paling efisien. Zoning dan sentralisasi memberikan hasil terbaik kedua dan ketiga.
\end{abstract}

Kata Kunci: sentralisasi, desentralisasi, zoning, program linier, masalah transportasi 


\section{PENDAHULUAN}

Perubahan adalah suatu keniscayaan yang harus dilakukan oleh suatu organisasi untuk menghadapi tantangan lingkungan yang terjadi. Berubah untuk menjadi lebih baik dalam melaksanakan tugas pokok fungsi serta menghadapi tantangan yang ada. Tidak ada struktur baku yang dapat diterapkan pada satu strategi atau bentuk organisasi. Meskipun, suatu organisasi yang berhasil dalam melaksanakan tugas pokok dan fungsinya, akan menginspirasi organisasi lain (sejenis) untuk mengikuti pola yang sama. David (2011).

Direktorat Audit Kepabeanan dan Cukai (Dit AKC), sebagai organisasi dalam Direktorat Jenderal Bea dan Cukai (DJBC), melaksanakan beberapa perubahan besar sejak tahun 2013 untuk memenuhi tugas pokok dan fungsi Dit AKC. Pelaksanaan perubahan dimulai dengan pelaksanaan Sentralisasi setelah pelaksanaan Desentralisasi pada era sebelumnya sesuai Instruksi Direktur Jenderal BC Nomor INS-4/BC/2013. Pada masa ini, seluruh unit audit pada DJBC dipusatkan di Dit AKC. Kemudian, pada 2017, Dit AKC mengeluarkan kebijakan baru dalam bentuk zonasi untuk unit audit pada DJBC sesuai Keputusan Direktur Jenderal Bea dan Cukai Nomor Kep355/BC/2017.

Dua bentuk perubahan di atas menyebabkan perubahan yang besar untuk unit Audit di DJBC. Untuk itu, perlu dilakukan evaluasi atas bentuk-bentuk perubahan yang telah dilakukan. Hal ini perlu dilakukan untuk mengetahui bentuk perubahan yang memberikan hasil terbaik. Yunindar dan Nugroho (2018) menyatakan terdapat lima faktor keberhasilan pelaksanaan sentralisasi audit, yaitu: nilai temuan audit, biaya perjalanan dinas, standardisasi kualitas audit, pertukaran informasi dan komunikasi internal tim audit dan antar pegawai, serta kebijakan penentuan objek audit.

Dari lima faktor di atas, biaya perjalanan dinas adalah faktor yang langsung memberikan beban terhadap keuangan negara. Biaya perjalanan dinas merupakan biaya yang dibayar unit audit dalam pelaksanaan tugas audit di lapangan. Biaya ini terdiri atas: Biaya transportasi berangkat dan pulang dari lokasi auditee, biaya penginapan, serta uang harian. (PMK nomor 113/PMK.05/2012)

Penelitian ini bertujuan mengukur efisiensi pelaksanaan audit dalam bentuk organisasi desentralisasi, sentralisasi, dan zoning. Efisiensi yang akan diukur adalah dari nilai perjalanan dinas pelaksanaan audit.

Penelitian ini menggunakan pendekatan program linier masalah transportasi, yang digunakan dalam memberikan alternatif pemecahan masalah transportasi, seperti dilakukan oleh Kumar (2018) yang menggunakan teknik program linier dan meteode modifikasi distribusi untuk menyelesaikan masalah balanced and unbalanced intuitionistic fuzzy transportation problems. Sedangkan Liang (2012), menggunakan possibilistic linear programming untuk menyelesaikan integrasi manufacturing/distribution planning decision (MDPD) dengan berbagai tujuan yang tidak presisi rantai suplai dalam kondisi ketidakpastian.

Biaya di atas harus dikendalikan, karena keterbatasan anggaran negara dalam memenuhi kebutuhan perjalanan dinas pelaksanaan audit. Ini selaras dengan salah satu isi Instruksi Menteri Keuangan 
agar terdapat kampanye efisiensi sebagai bentuk peneguhan budaya dalam kementerian keuangan, yaitu "pembatasan frekuensi dan jumlah peserta perjalanan dinas" (IMK nomor 346/IMK.01/2017). Penelitian ini berusaha memberikan evaluasi atas perubahan yang dilakukan Direktorat Audit Kepabeanan dan Cukai, dalam bentuk simulasi pelaksanaan zonasi dan desentralisasi menggunakan program linier atas data faktual pelaksanaan audit secara sentralisasi pada tahun 2016. Diharapkan dari pelaksanaan simulasi ini akan didapatkan hasil yang memperlihatkan bentuk perubahan organisasi yang memberikan hasil yang paling efisien dalam hal biaya perjalanan dinas audit.

Rumusan masalah dalam penelitian ini terbagi menjadi tiga rumusan, yaitu:

1. Berapakah estimasi biaya perjalanan dinas pelaksanaan audit dalam bentuk desentralisasi?

2. Berapakah estimasi biaya perjalanan dinas pelaksanaan audit dalam bentuk sentralisasi?

3. Berapakah estimasi biaya perjalanan dinas pelaksanaan audit dalam bentuk zoning?

4. Bentuk organisasi apakah yang memberikan efisiensi biaya perjalanan dinas pelaksanaan audit terbaik?

Tujuan pelaksanaan penelitian ini adalah:

1. Untuk mengestimasi nilai biaya perjalanan dinas pelaksanaan audit dalam bentuk desentralisasi
2. Untuk mengestimasi nilai biaya perjalanan dinas pelaksanaan audit dalam bentuk sentralisasi

3. Untuk mengestimasi nilai biaya perjalanan dinas pelaksanaan audit dalam bentuk zoning

4. Untuk menganalisis bentuk organisasi yang memberikan efisiensi (biaya terendah) terbaik

Adapun manfaat yang dapat diperoleh melalui penelitian ini antara lain:

a. Sebagai bentuk informasi dan bahan evaluasi bagi Direktorat Audit Kepabeanan dan Cukai atas pelaksanaan piloting zoning audit.

b. Memberikan alternatif bentuk organisasi serta penempatan pegawai yang memberikan hasil efisiensi maksimal.

\section{KAJIAN LITERATUR}

\subsection{Perubahan Organisasi}

Perubahan organisasi merupakan suatu keniscayaan yang harus dihadapi oleh organisasi untuk menyesuaikan dengan tantangan perubahan lingkungan. David (2011) menyatakan bahwa organisasi paling berhasil saat ini adalah yang mampu beradaptasi secara cepat dan terusmenerus terhadap perubahan. Para manajer perlu mengantisipasi serta menginisiasi perubahan.

Pernyataan di atas juga menyarankan kepada para manajer untuk secara kreatif membuat pembaharuan dalam organisasinya dalam mengantisipasi perubahan. Pangarkar (2015), menyatakan kondisi ekonomi dan pergantian peraturan merupakan contoh faktor perubahan yang menyebabkan manajer organisasi melaksanakan perubahan pada strateginya.

\subsection{Efisiensi}


Salah satu konsep yang digunakan dalam mengukur kinerja keuangan adalah efisiensi. Konsep efisiensi ini digunakan dalam meneliti perilaku pengeluaran biaya. Arens, Elder, dan Beasley (2012) mendefinisikan Efisiensi sebagai "to determining the resources used to achieve those objectives, such as determining whether parts are produced at minimum cost". Efisiensi digunakan untuk menunjukkan suatu proses yang memberikan pengeluaran minimum.

\subsection{Sentralisasi, Desentralisasi. dan Zoning}

Sentralisasi dan desentralisasi merupakan bentuk proses pengambilan keputusan dalam suatu organisasi. Hill dan Jones (1995), serta Cummings (1995), mengemukakan suatu organisasi memiliki bentuk sentralisasi apabila otorisasi pengambilan keputusan penting terdapat pada manajer tingkat tinggi.

Sedangkan untuk desentralisasi, Cummings (1995) menyatakan sebagai otonomi pengambilan keputusan oleh daerah. Kekuasaan pengambilan keputusan bergeser dari manajer pusat ke daerah.

Berdasarkan pengertian yang disampaikan Hill dan Jones serta Cummings, dapat disimpulkan bahwa bahwa sentralisasi adalah bentuk kewenangan pengambilan keputusan dalam organisasi yang ditentukan oleh pemimpin atau pusat organisasi. Sedangkan desentralisasi adalah bentuk kewenangan pengambilan keputusan dalam organisasi diberikan kepada manajer daerah.

Desentralisasi pelaksanaan audit pada DJBC dilaksanakan dalam dua bentuk, pertama, sebelum pelaksanaan Instruksi nomor INS-4/BC/2013. Pelaksanaan audit dalam era ini dilakukan oleh seluruh
Kantor Wilayah dan Kantor Pelayanan Utama di Direktorat Jenderal Bea dan Cukai serta Direktorat Audit. Bentuk kedua dalam pelaksanaan desentralisasi dilakukan dalam bentuk zoning, yaitu lima Kantor Wilayah dan satu Kantor Pelayanan Utama yang melakukan kegiatan audit kepabeanan dan cukai. Bentuk zoning ini sesuai dengan Kep355/BC/2017.

\subsection{Audit Kepabeanan dan Cukai}

Arens, Elder, dan Beasley (2012) mendefinisikan Audit sebagai

"is the accumulation and evaluation of evidence about information to determine and report on the degree of correspondence between the information and established criteria. Auditing should be done by a competent, independent person".

Untuk Audit Kepabeanan, PMK nomor 200/PMK.04/2011 mendefinisikan sebagai kegiatan pemeriksaan laporan keuangan dan dasarnya, dokumen kegiatan kepabeanan, dan/atau sediaan barang yang digunakan untuk memenuhi ketentuan peraturan kepabeanan.

Sedangkan Audit Cukai memiliki definisi yang mirip dengan audit kepabeanan, namun memiliki perbedaan dokumen kegiatan yang digunakan adalah dokumen cukai dan ditujukan untuk memenuhi ketentuan peraturan cukai,

Penelitian ini menggunakan seluruh Audit Kepabeanan dan Audit Cukai yang dilaksanakan oleh Unit Audit di Direktorat Jenderal Bea dan Cukai.

\subsection{Biaya Perjalanan Dinas}

Biaya perjalanan dinas merupakan biaya yang dibayar unit audit untuk setiap pelaksanaan tugas audit di lapangan. Dalam pelaksanaan audit, pelaksanaan di lapangan adalah bentuk perjalanan dinas dalam rangka pelaksanaan tugas dan 
fungsi yang melekat pada jabatan. Sesuai dengan peraturan perjalanan dinas pegawai negeri sipil, biaya yang ditanggung dalam perjalanan adalah biaya transportasi berangkat dan pulang dari lokasi auditee, biaya penginapan, dan uang harian (PMK nomor 113/PMK.05/2012). Penelitian ini menggunakan data surat tugas pelaksanaan audit yang dilaksanakan oleh auditor di unit Audit Direktorat Jenderal Bea dan Cukai, Standar Biaya Masukan tahun 2016 berdasarkan PMK nomor 65/PMK.02/2015, dan data biaya penerbangan.

\subsection{Penelitian Terdahulu}

Yunindar dan Nugroho (2018), meneliti faktor-faktor keberhasilan penerapan sentralisasi pada Direktorat Audit (sekarang Dit AKC) serta tingkat keberhasilan Direktorat ini dalam penerapan sentralisasi. Penelitian ini menggunakan metode kualitatif dengan hasil lima faktor menunjukkan hasil lebih baik setelah dilaksanakan sentralisasi, yaitu: nilai temuan, biaya perjalanan dinas, standardisasi kualitas audit, pertukaran informasi dan komunikasi internal tim audit dan antar pegawai, serta kebijakan penentuan objek audit. Selain itu, bentuk sentralisasi digunakan untuk memaksimalkan kepentingan dan legitimasi dari pihak yang memiliki kewenangan/kekuatan serta meningkatkan efektifitas organisasi. (Stroup dan Wong, 2013). Muchadenyika dan William (2018) juga menemukan bahwa struktur sentralisasi digunakan untuk mempertahankan kekuasaan atau kewenangan. Sentralisasi juga meningkatkan kepatuhan karyawan (Dedahanov, Kim, dan Rhee, 2015). Di sisi lain, Kaufmann, Borry, dan DehartDavis (2018) menemukan bahwa sentralisasi menyebabkan lebih banyak birokrasi di organisasi pemerintah.
Terkait desentralisasi, Chang dan Harrington (2000) menemukan bahwa desentralisasi dapat meningkatkan performa perusahaan perusahaan retail apabila pasar dari toko adalah cukup berbeda dan stabil serta diukur dalam waktu yang lama. Bentuk desentralisasi juga sesuai untuk diterapkan pada bentuk organisasi yang terdiri atas bagian-bagian yang memiliki prinsip berbeda, seperti kasus di Irak yang terdiri atas tiga faksi, yaitu: suni, syiah, dan kurdi. (O'driscoll, 2017). Selain itu, desentralisasi juga menyebabkan manajer tingkat bawah di rumah sakit Amerika mengadopsi lebih sering inovasi-inovasi yang ada. (Moch dan Morse, 1977)

Volders (2016), dalam penelitian organisasi terorisme menyatakan bahwa sentralisasi menghasilkan keputusan yang pasti, arus informasi yang lebih baik, meningkatkan kekuasaan dan mekanisme pengendalian, serta meningkatkan spesialisasi. Sedangkan desentralisasi dapat meningkatkan fleksibilitas dan motivasi anggota

Penelitian Rodniski dan Diehl (2012) menemukan bahwa dalam organisasi sentralisasi, sistem informasi akuntansi lebih difokuskan untuk hasil organisasi secara keseluruhan daripada hasil non keuangan serta informasi kualitatif. Untuk organisasi desentralisasi, sistem informasi lebih ditujukan untuk hasil divisi.

Sedangkan O'brien, Hartnett, dan Rawlins (2019) menyatakan dalam pengelolaan manajemen e-learning institusi pendidikan, struktur organisasi yang baik dapat berbentuk desentralisasi, sentralisasi, dan sangat sentralisasi, bergantung kepada jumlah anggota tim, peran anggota tim, dan fungsi terpusat yang diinginkan.

Kumar (2018), meneliti penyelesaian masalah balanced and unbalanced intuitionistic fuzzy transportation problems. Penelitian ini menggunakan metode kuantitatif dengan teknik program 
linier dan metode modifikasi distribusi. Hasil penelitian ini menunjukkan penggunaan metode modifikasi distribusi menghasilkan format evaluasi yang lebih mudah digunakan.

Sedangkan Liang (2012), meneliti penyelesaian masalah integrasi manufacturing/distribution planning decision (MDPD) dengan berbagai tujuan yang tidak presisi rantai suplai dalam kondisi ketidakpastian. Metode kuantitatif dengan possibilistic linear programming digunakan dalam penelitian ini. Hasil penelitian ini menunjukkan metode yang digunakan memberikan kepraktisan penggunaan dan secara efektif memperbaiki hubungan rantai suplai pabrik/distributor.

\subsection{Kerangka Pemikiran}

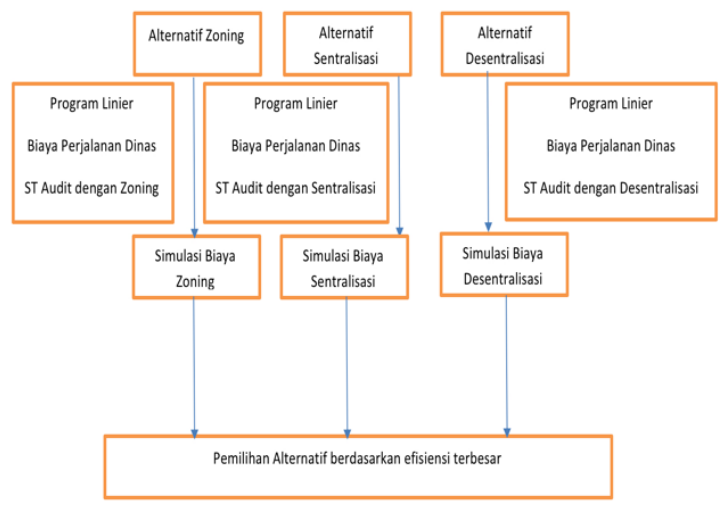

\section{METODE PENELITIAN}

\subsection{Waktu dan Tempat Penelitian}

Penelitian ini dilakukan pada Direktorat Audit Kepabeanan dan Cukai Direktorat Jenderal Bea dan Cukai dan data yang diambil pada tahun 2016 .

\subsection{Desain Penelitian}

Penelitian ini merupakan penelitian deskriptif kuantitatif. Data yang dipakai dalam penelitian ini adalah data sekunder. Data sekunder yang dipergunakan dalam penelitian ini adalah data biaya perjalanan dinas, surat tugas audit, standar biaya masukan, jumlah tim audit, dan struktur organisasi unit audit.

\subsection{Definisi dan Operasionalisasi Variabel}

\subsubsection{Efisiensi}

Konsep efisiensi yang digunakan dalam penelitian ini adalah menentukan proses pelaksanaan audit di antara tiga alternative yang memberikan pengeluaran minimum.

\subsubsection{Sentralisasi}

Sentralisasi dalam penelitian ini adalah pelaksanaan audit dalam bentuk terpusat. Seluruh perjalanan tugas audit dilaksanakan oleh tim audit Direktorat Audit Kepabeanan dan Cukai yang berkantor di Jakarta

\subsubsection{Desentralisasi}

Desentralisasi dalam penelitian ini adalah pelaksanaan audit dalam bentuk terbagi ke Unit Audit di seluruh Kantor Vertikal Eselon II di Direktorat Jenderal Bea dan Cukai. Tim audit dari Direktorat Audit, diasumsikan dibagi ke seluruh Kantor Vertikal Eselon II. Seluruh perjalanan tugas audit dilaksanakan oleh tim audit dari Unit Audit di Kantor Vertikal Eselon II yang berkantor di 18 tempat di Indonesia.

\subsubsection{Zoning}

Zoning dalam penelitian ini adalah pelaksanaan audit dalam bentuk terbagi ke beberapa Unit Audit di Kantor Vertikal Eselon II yang ditunjuk di Direktorat Jenderal Bea dan Cukai. Tim audit dari Direktorat Audit, diasumsikan dibagi ke enam Kantor Vertikal Eselon II. Seluruh perjalanan tugas audit dilaksanakan oleh tim audit dari Unit Audit di Kantor Vertikal Eselon II yang berkantor di 6 tempat di Indonesia.

\subsubsection{Pelaksanaan Audit Kepabeanan dan Cukai}

Pelaksanaan Audit Kepabeanan dan Cukai yang digunakan penelitian ini adalah kegiatan audit pejabat Bea Cukai dalam melaksanakan Audit Kepabenan dan Audit Cukai.

\subsubsection{Biaya Perjalanan Dinas}


Biaya perjalanan dinas merupakan biaya yang dibayar unit audit untuk setiap pelaksanaan tugas audit di lapangan. Biaya ini dihitung dari Kantor Unit Audit ke tempat auditee. Biaya ini terdiri dari biaya transportasi berangkat dan pulang dari lokasi auditee, biaya penginapan, dan uang harian.

\section{TEKNIK PENGUMPULAN DATA}

Teknik pengumpulan data dilakukan menggunakan metode dokumentasi terhadap data-data sekunder yaitu mengumpulkan dan mencatat data dari Direktorat Audit Kepabeanan dan Cukai berupa: surat tugas audit, standar biaya masukan, jumlah tim audit, dan struktur organisasi unit audit pada tahun 2016. Digunakan juga data dari website maskapai penerbangan.

\section{METODE ANALISIS}

Penelitian ini menggunakan program linier masalah transportasi dengan bantuan solver di program Microsoft Excel. Tahapan pelaksanaan penelitian akan dilaksanakan sebagai berikut:

a. Rekapitulasi data surat tugas audit untuk mendapatkan jumlah penugasan audit di setiap provinsi

b. Menentukan data biaya perjalanan dinas untuk setiap provinsi di Indonesia

c. Melakukan simulasi pelaksanaan audit dengan menggunakan asumsi sentralisasi, zoning, dan desentralisasi dengan tujuan minimalisasi biaya. Simulasi dilakukan dengan membuat data masalah distribusi dalam bentuk desentralisasi

Langkah simulasi untuk sentralisasi adalah:

- Misal xij adalah jumlah tim audit yang berangkat dari kantor i dan dilakukan oleh Direktorat Audit Kepabeanan dan Cukai dengan $i=1$ dan $j=1,2,3, \ldots, 11$
- Formulasi program linier dengan

Minimasi biaya

$\mathrm{ax} 11+\mathrm{bx} 12+\mathrm{cx} 13+\ldots .+\mathrm{fx} 6111$

Dengan syarat

$\mathrm{x} 11+\mathrm{x} 12+\mathrm{x} 13+\ldots .+\mathrm{x} 111=\mathrm{M}$

Langkah simulasi untuk desentralisasi adalah:

- Misal xij adalah jumlah tim audit yang berangkat dari kantor $i$ dan dilakukan pada provinsi $\mathrm{j}$, dengan $i=1,2,3, \ldots, 23$ dan $j=1,2,3, \ldots, 11$

- Formulasi program linier dengan Minimasi biaya

$\mathrm{ax} 11+\mathrm{bx} 12+\mathrm{cx} 13+\ldots .+\mathrm{xx} 1811$

Dengan syarat:

$\mathrm{x} 11+\mathrm{x} 12+\mathrm{x} 13+\ldots .+\mathrm{x} 111=\mathrm{M}$

$\mathrm{x} 181+\mathrm{x} 182+\mathrm{x} 183+\ldots+\mathrm{x} 1811=\mathrm{P}$

Melakukan simulasi pelaksanaan audit dengan menggunakan asumsi zoning dengan tujuan minimalisasi biaya. Simulasi dilakukan dengan membuat data masalah simulasi dalam bentuk zoning.

Langkah simulasi untuk zoning adalah:

- Misal xij adalah jumlah tim audit yang berangkat dari kantor i dan dilakukan pada provinsi $\mathrm{j}$, dengan $i=1,2,3 \ldots, 6$ dan $j=1,2,3, \ldots, 11$

- Formulasi program linier dengan

Minimasi biaya

$a x 11+b x 12+c x 13+\ldots .+x \times 611$

Dengan syarat

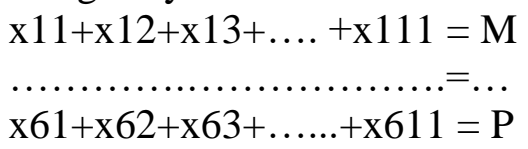

Melakukan perbandingan total biaya pelaksanaan audit di antara tiga alternatif 
dan memilih alternatif yang memberikan efisiensi terbaik.

\section{HASIL DAN PEMBAHASAN}

Hasil penelitian ini berupa simulasi jumlah biaya perjalanan dinas masingmasing asumsi, dengan menggunakan alat bantu solver program excel dengan menggunakan asumsi program linier. Penggunaan program linier adalah untuk menghasilkan nilai minimum dari total biaya perjalanan dinas untuk asumsi desentralisasi, sentralisasi, dan zoning

\subsection{Simulasi Sentralisasi}

Simulasi Sentralisasi menghasilkan total biaya yang diperlukan oleh Direktorat Jenderal Bea dan Cukai (DJBC) dalam melaksanakan audit kepabeanan dan cukai pada tahun 2016 adalah Rp. 14.222.909.000 (lampiran I) untuk pelaksanaan 344 audit di 11 kelompok lokasi penugasan.

Simulasi Sentralisasi memasukkan jumlah tim audit dari unit fungsional di DJBC. Diasumsikan dalam simulasi ini, tim audit dari unit fungsional dapat melakukan audit sebanyak 5 kali dalam setahun. Dasar asumsi ini adalah ketentuan waktu penyelesaian audit kepabeanan cukai adalah 3 bulan, sehingga dalam satu tahun diprediksikan satu tim audit dapat menyelesaikan minimal 4 penugasan reguler. Selain itu, satu tim audit juga dapat diberikan 1 penugasan sewaktu-waktu apabila tim audit dapat menyelesaikan audit kurang dari 3 bulan.

\footnotetext{
Hasil perhitungan di atas menunjukkan kapasitas maksimal kemampuan audit Direktorat Jenderal Bea dan Cukai adalah sebesar 375 (terdapat 75 tim audit). Bila dibandingkan dengan jumlah penugasan tahun 2016 sebesar 344 penugasan, terdapat selisih 31 penugasan audit.
}

\subsection{Simulasi Desentralisasi}

Hasil simulasi desentralisasi menunjukkan bahwa total biaya yang diperlukan oleh Direktorat Jenderal Bea dan Cukai (DJBC), untuk pelaksanaan audit kepabeanan dan cukai pada tahun 2016 adalah senilai Rp. 7.383.495.000 untuk pelaksanaan 344 audit di 11 kelompok lokasi auditee.

Simulasi Desentralisasi memasukkan jumlah tim audit dari unit fungsional dan struktural. Tim audit dari unit fungsional berdasar data tim audit sesuai pelaksanaan piloting zoning audit di DJBC. Sedangkan tim audit struktural berdasar atas data pegawai struktural yang memiliki kualifikasi auditor di kanwil atau KPU non piloting zoning audit.

Diasumsikan dalam simulasi ini, tim audit dari unit fungsional dapat melakukan audit sebanyak 5 kali dalam setahun. Asumsi ini didasarkan pada ketentuan waktu penyelesaian audit kepabeanan dan cukai adalah 3 bulan, sehingga untuk fungsional dalam satu tahun dapat menyelesaikan minimal 4 penugasan reguler. Selain itu, fungsional auditor juga dapat diberikan 1 penugasan sewaktuwaktu apabila tim audit dapat menyelesaikan audit kurang dari 3 bulan.

Sedangkan tim audit dari unit struktural, setiap tim diasumsikan dapat melakukan audit sebanyak dua kali dalam setahun. Dasar asumsi ini adalah pekerjaan audit tim struktural merupakan tugas tambahan yang dapat dilakukan di luar tugas pokok pekerjaan struktural.

Lampiran II yang merupakan hasil simulasi penugasan dengan biaya minimal untuk asumsi desentralisasi, menunjukkan terdapat lima lokasi yang seluruh tim auditnya mendapatkan penugasan maksimal audit sesuai kapasitas audit per wilayah. Kelima wilayah itu adalah: Denpasar (Kanwil Bali, Nusa Tenggara 
Barat, Nusa Tenggara Timur), Banjarmasin (Kanwil Kalimantan Selatan), Tangerang (Kanwil Banten dan KPU Soekarno Hatta), Bandung (Kanwil Jawa Barat), dan Semarang (Kanwil Jawa Tengah).

Selain itu, lampiran II juga memperlihatkan enam lokasi yang penugasan auditnya di bawah kapasitas maksimal audit. Lokasi-lokasi itu adalah: Jakarta (Kantor Pusat dan KPU Tanjung Priok), Balikpapan (Kanwil Kalimantan Timur), Batam (Kanwil Khusus Kepri dan KPU Batam), Palembang (Kanwil Sumatera Bagian Selatan), Medan (Kanwil Sumatera Bagian Utara), dan Surabaya (Kanwil Jawa Timur I dan Kanwil Jawa Timur II).

Sedangkan 7 lokasi lainnya tidak mendapatkan alokasi penugasan. Ketujuh lokasi itu yaitu: Pontianak (Kanwil Kalimantan Bagian Barat), Ambon (Kanwil Maluku), Banda Aceh (Kanwil Aceh), Pekanbaru (Kanwil Riau), Makassar (Kanwil Sulawesi Selatan), Lampung (Kanwil Sumatera Bagian Barat), dan Manado (Kanwil Sulawesi Bagian Utara.

Simulasi Desentralisasi menunjukkan bahwa lokasi Jakarta menggunakan biaya perjalanan dinas paling besar, yaitu: Rp. 4.639.460.000. Sedangkan lokasi Palembang (Kanwil Sumatera Bagian Selatan) menyerap biaya perjalanan paling sedikit (Rp. 39.910.000).

\subsection{Simulasi Zoning}

Simulasi terakhir, yaitu zoning, memperlihatkan bahwa biaya yang diperlukan oleh Direktorat Jenderal Bea dan Cukai (DJBC) untuk melaksanakan audit kepabeanan dan cukai pada tahun 2016 adalah Rp. 7.710.605.000 untuk pelaksanaan 344 audit di 11 kelompok lokasi auditee.
Simulasi ini memasukkan jumlah tim audit dari unit. Tim audit dari unit fungsional berdasar data tim audit sesuai pelaksanaan piloting zoning audit di DJBC. Diasumsikan dalam simulasi ini, tim audit dari unit fungsional dapat melakukan audit sebanyak 5 kali dalam setahun. Perhitungan ini didasarkan pada ketentuan waktu penyelesaian audit kepabeanan dan cukai adalah 3 bulan, sehingga untuk fungsional dalam satu tahun dapat menyelesaikan minimal 4 penugasan reguler. Selain itu, fungsional auditor juga dapat diberikan 1 penugasan sewaktu-waktu apabila tim audit dapat menyelesaikan audit kurang dari 3 bulan.

Lampiran III yang merupakan hasil simulasi penugasan dengan biaya perjalanan dinas minimal untuk asumsi zoning, menunjukkan terdapat empat lokasi yang seluruh tim auditnya mendapatkan penugasan maksimal audit sesuai kapasitas audit per wilayah. Keempat wilayah itu adalah: Tangerang (Kanwil Banten), Bandung (Kanwil Jawa Barat), Semarang (Kanwil Jawa Tengah), dan Surabaya (Kanwil Jawa Timur 1).

Lampiran II juga memperlihatkan dua lokasi yang penugasan auditnya di bawah kapasitas maksimal audit. Lokasi-lokasi itu adalah: Jakarta (Kantor), dan Medan (Kanwil Sumatera Bagian Utara).

Simulasi Zoning menunjukkan bahwa Jakarta merupakan lokasi yang menggunakan biaya perjalanan dinas paling besar, yaitu: Rp. 5.934.385.000. Sedangkan lokasi Medan (Kanwil Sumatera Bagian Utara) menghabiskan biaya perjalanan paling sedikit (Rp. 158.430.000).

\subsection{Pembahasan}

Ketiga simulasi di atas menunjukkan estimasi total biaya perjalanan dinas terendah yang dapat dicapai untuk masingmasing bentuk organisasi. Total biaya ini 
adalah nilai biaya hipotesis, karena didapatkan dengan menggunakan standar waktu dan biaya. Sedangkan praktik di lapangan dapat berbeda, karena waktu dan biaya dapat bervariasi sesuai dengan kondisi penugasan. Selain itu, penelitian ini mensimulasikan terdapat lokasi dapat menggunakan secara penuh, sebagian, dan tidak menggunakan sama sekali kemampuan auditnya.

Simulasi penelitian ini menunjukkan urutan total penggunaan biaya perjalanan dinas dari biaya terendah ke tertinggi adalah: 1. asumsi desentralisasi dengan biaya Rp. 7.383.495.000; 2. asumsi zoning dengan biaya Rp. 7.710.605.000; 3. serta asumsi sentralisasi sebesar Rp. 14.222.909.000.

Hasil penelitian ini berbeda dengan Yunindar dan Nugroho. Penelitian Yunindar dan Nugroho menunjukkan bahwa sentralisasi memberikan hasil nilai biaya perjalanan dinas yang lebih efisien. Perbedaan ini dapat terjadi karena perbedaan metode yang digunakan, yaitu realisasi biaya dan estimasi biaya. Selain itu, penelitian ini menggunakan prinsip unit terdekat dengan obyek audit yang melakukan audit sebagai salah satu asumsi dalam penentuan biaya perjalanan dinas. Metode realisasi tidak menggunakan asumsi ini sehingga dimungkinkan unit yang terjauh dari objek audit dapat melakukan audit.

Selain itu, simulasi penelitian juga menunjukkan, bahwa dalam semua simulasi, terdapat tempat yang tidak dapat menggunakan secara maksimal kapasitas auditnya. Sedangkan dalam simulasi desentralisasi, terdapat juga beberapa lokasi, untuk tujuan efisiensi biaya, tidak mendapatkan alokasi penugasan audit.

Berdasarkan hal-hal di atas, penggunaan asumsi yang memberikan hasil efisien adalah simulasi desentralisasi, untuk penugasan 2016, karena memberikan biaya perjalanan dinas terendah. Simulasi desentralisasi memberikan biaya lebih rendah $\mathrm{Rp}$. 327.110.000 dibandingkankan simulasi zoning dan lebih rendah Rp. 6.839.414.000 dibandingkan simulasi sentralisasi. Namun, pemilihan asumsi desentralisasi perlu mempertimbangkan mendalam pembukaan unit audit di lokasilokasi yang disimulasikan tidak akan mendapatkan penugasan audit.

\section{SIMPULAN DAN SARAN/ REKOMENDASI}

Perubahan organisasi untuk mencapai tujuan organisasi adalah suatu keniscayaan dalam perkembangan organisasi. Sentralisasi, Desentralisasi, dan Zoning adalah beberapa bentuk organisasi yang dapat digunakan oleh Direktorat Jenderal Bea dan Cukai (DJBC) dalam membentuk unit audit kepabeanan dan cukai. Salah satu hal yang menjadi perhatian Pimpinan Kementerian Keuangan, selaku Kementerian tempat DJBC bernaung, adalah penggunaan biaya perjalanan dinas yang efisien. Pendekatan program linier masalah transportasi, membantu memberikan hasil paling efisien untuk masing-masing bentuk organisasi dengan memperhatikan hambatan atau kendala untuk masing-masing bentuk. Simulasi asumsi desentralisasi, diprediksikan dapat memberikan biaya perjalanan dinas paling efisien. Hasil ini dapat berbeda dengan realisasi di lapangan apabila unit audit di daerah diberikan kebebasan secara mutlak untuk menentukan sendiri objek auditnya. Perlu diperhatikan bahwa pembukaan unit audit di daerah adalah dalam rangka mendekatkan unit audit kepada objek auditnya. Selain itu, bila Direktorat audit Kepabeanan dan cukai memilih struktur desentralisasi, disarankan untuk tidak melakukan pembukaan unit audit di lokasi 
yang diperkirakan tidak mendapat penugasan dalam asumsi desentralisasi.

\section{KETERBATASAN PENELITIAN}

Terdapat beberapa hal yang menjadi keterbatasan dalam penelitian ini, yaitu:

a. Pengambilan data pada tahun 2016

b. Penggunaan Standar Biaya Masukan, untuk menentukan biaya perjalanan dinas

c. Penggunaan asumsi pelaksanaan audit

\section{DAFTAR PUSTAKA}

Arens, Alvin A., Elder, Randal J., dan Beasley, Mark S. 2012. Auditing and assurance services: an integrated approach. 14th ed. New Jersey: Pearson Education, Inc.

Chang, Myong-Hun dan Harrington, Joseph E, Jr. 2000. Centralization vs. Decentralization in a MultiUnit Organization: A

Computational Model of a Retail Chain as a Multi-Agent Adaptive System. Management Science, Vol. 46, No. 11: 1427-1440.

Cummings, Stephen. 1995. Centralization and Decentralization: The NeverEnding Story of Separation and Betrayal. Scand. J. Mgmt, Vol. 11, No. 2: 103-117.

David, Fred R. 2011. Strategic Management: Concepts and Cases. $13^{\text {th }}$ ed. New Jersey: Pearson Education, Inc.

Dedahanov, Alisher Tohirovich., Kim, Choonghyun., dan Rhee, Jaehoon. 2015. Centralization and Communication Opportunities as Predictors of Acquiescent or
Prosocial Silence. Social Behavior and Personality, 43, 3: 481-492

Hill, Charles W. L. and Gareth R. Jones 1995. Strategic Management an Integrated Approach. $3^{\text {rd }}$ ed. USA: Houghton Mifflin Company.

Kaufmann, Wesley., Borry, Erin L., dan Dehart-Davis, Leisha. 2018. More than Pathological Formalization: Understanding Organizational Structure and Red Tape. Public Administration Review, Vol. 79, Iss. 2: 236-245

Kumar, Senthil P. 2018. Liniar Programming Approach for Solving Balanced and Unbalanced Intuitionistic Fuzzy Transportation Problems. International Journal of Operations Research and Information Systems, Vol 9 Issue 2: 73-100

Liang, Tien-Fu. 2012. Integrated Manufacturing/Distribution Planning Decisions with Multiple Imprecise Goals in an Uncertain Environment. Qual Quant, 46: 137153

Moch, Michael K., dan Morse, Edward V. 1977. Size, Centralization and Organizational Adoption of Innovations. American Sociological Review, Vol. 42: 716725

Muchadenyika, Davison. dan William, John J. 2018. Politics, Centralisation and Service Delivery in Urban Zimbabwe. Journal of Southern African Studies, Vol. 44, No. 5: 833-853

O'brien, Ray., Hartnett, Maggie. dan Rawlins, Peter. 2019. The centralisation of elearning 
resource development within the New Zealand vocational tertiary education sector. Australasian Journal of Educational Technology, 35(5): 95-110.

O'driscoll, Dylan. 2017, Autonomy Impaired: Centralisation, Authoritarianism and the Failing Iraqi State. Ethnopolitics. Vol. 16, No. 4, 315-332

Rodniski, Cleber Marcos dan Diehl, Carlos Alberto. 2012. The Role of the Controllership Regarding the Degree of Centralization of Organizations. Sociedade, Contabilidade e Gestão, v. 7, n. 1: 7-22

Stroup, Sarah S. dan Wong, Wendy H. 2013. Come Together? Different Pathways to International NGO Centralization. International Studies Review, 15: 163-184

Volders, Brecht. 2016. Assessing the Terrorist Threat: Impact of the Group's Organizational Design? Studies in Conflict \& Terrorism, Vol. 39, No. 2: 106-127

Yunindar, Shinta Ayu Sri dan Nugroho, Ario Seno. 2018. Evaluasi Atas Penerapan Sentralisasi Pada Direktorat Audit Kepabeanan dan Cukai. Jurnal Perspektif Bea dan Cukai Vol 2, No 1:14-25

Peraturan Menteri Keuangan Republik Indonesia Nomor 200/PMK.04/2011 tentang Audit Kepabeanan dan Cukai

Peraturan Menteri Keuangan Republik Indonesia Nomor 113/PMK.05/2012 tentang Perjalanan Dinas Dalam Negeri
Bagi Pejabat Negara, Pegawai Negeri, dan Pegawai Tidak Tetap.

Peraturan Menteri Keuangan Republik Indonesia Nomor 65/PMK.02/2015 tentang Standar Biaya Masukan Tahun Anggaran 2016.

Instruksi Menteri Keuangan Republik Indonesia Nomor 346/PMK.01/2017 tentang Gerakan Efisiensi Sebagai Bagian Implementasi Penguatan Budaya Kementerian Keuangan.

Instruksi Direktur Jenderal Bea dan Cukai Nomor INS-4/BC/2013 tentang Penerapan Sentralisasi Jabatan Fungsional Pemeriksa Bea dan Cukai Sub Unsur Audit Kepabeanan dan Cukai.

Keputusan Direktur Jenderal Bea dan Cukai Nomor Kep-355/BC/2017 tentang Piloting Pelaksanaan Fungsi Audit Kepabeanan dan Cukai pada Kantor Wilayah Direktorat Jenderal Bea dan Cukai. 
Vol. 4, No. 1, 2020

Lampiran I

TABEL PENUGASAN AUDIT DAN BIAYA PERJALANAN DINAS SIMULASI SENTRALISASI

\begin{tabular}{|c|c|c|c|c|c|c|c|c|c|c|c|c|c|c|c|c|c|}
\hline & TUJUAN & W1 & W2 & W3 & W4 & W5 & W6 & W7 & W8 & W9 & W10 & & W11 & \multirow{3}{*}{ Kapasitas } & \multirow{3}{*}{ Penugasan } & \multirow{3}{*}{ SISA } & \multirow{2}{*}{ TOTAL BIAYA } \\
\hline & & BALI & BANTEN & JAKARTA & JAWA BARAT & JAWA TENGAH & JAWA TIMUR & KALIMANTAN & KEPULAUANRIAU & \begin{tabular}{|l|l|} 
SUMATERA BARAT \\
\end{tabular} & SUMATERA SELATAN & SUMAT & ERA UTARA & & & & \\
\hline ASAL & & RIBUAN & RIBUAN & RIBUAN & RIBUAN & RIBUAN & RIBUAN & RIBUAN & RIBUAN & RIBUAN & RIBUAN & & RIBUAN & & & & RIBUAN \\
\hline \multirow[t]{3}{*}{ s1 } & jakarta & \begin{tabular}{l|l|}
12 & Rp1,131,360 \\
\end{tabular} & \begin{tabular}{l|l|}
30 & Rp1,901,160 \\
\end{tabular} & \begin{tabular}{|l|l|}
147 & $\mathrm{Rp} 1,790,460$ \\
\end{tabular} & \begin{tabular}{l|l|}
92 & $\mathrm{Rp} 5,242,160$ \\
\end{tabular} & \begin{tabular}{|l|l|}
27 & $R p 1,592,082$ \\
\end{tabular} & \begin{tabular}{l|l|}
$26 p 1,841,814$ \\
\end{tabular} & Rp83,389 & \begin{tabular}{|l|l|}
1 & Rp 71,784 \\
\end{tabular} & \begin{tabular}{l|l|}
1 & $R p 68,632$ \\
\end{tabular} & Rp72,112 & 6 & Rp427,956 & 375 & 344 & 31 & Rp14,222, \\
\hline & KAPASITAS & 12 & 30 & 147 & 92 & 27 & 26 & 1 & 1 & 1 & 1 & 6 & & & & & \\
\hline & PENGGUNAAN & \begin{tabular}{l|l}
12 & Rp1,131,360 \\
\end{tabular} & $\begin{array}{lll}30 & \text { Rp1,901,160 } \\
\end{array}$ & \begin{tabular}{|c|c|}
147 & $\mathrm{Rp} 1,790,460$ \\
\end{tabular} & \begin{tabular}{l|l}
92 & $R p 5,242,160$
\end{tabular} & \begin{tabular}{l|l}
27 & $R p 1,592,082$ \\
\end{tabular} & \begin{tabular}{l|l|}
26 & Rp1,841,814 \\
\end{tabular} & 1) Rp83,389 & \begin{tabular}{|l|l|}
1 & $R p 71,784$ \\
\end{tabular} & 1) $\mathrm{Rp} 68,632$ & 1) $\mathrm{Rp} 72,112$ & 6 & Rp427,956 & & & & \\
\hline
\end{tabular}

Lampiran II

TABEL PENUGASAN AUDIT DAN BIAYA PERIALANAN DINAS SIMULASI DESENTRALISAS

\begin{tabular}{|c|c|c|c|c|c|c|c|c|c|c|c|c|c|c|c|c|c|c|c|c|c|c|c|c|c|c|c|}
\hline \multirow[b]{3}{*}{ ASAL } & \multirow{3}{*}{\begin{tabular}{l|} 
TUJUAN \\
\end{tabular}} & \multirow{2}{*}{\multicolumn{2}{|c|}{$\begin{array}{l}\text { W1 } \\
\text { BALI }\end{array}$}} & \multirow{2}{*}{\multicolumn{2}{|c|}{$\begin{array}{c}\text { W2 } \\
\text { BANTEN }\end{array}$}} & \multirow{2}{*}{\multicolumn{2}{|c|}{$\begin{array}{c}\text { W3 } \\
\text { JAKARTA }\end{array}$}} & \multirow{2}{*}{\multicolumn{2}{|c|}{$\frac{\text { W4 }}{\text { AWA BARAT }}$}} & \multirow{2}{*}{\multicolumn{2}{|c|}{$\frac{\text { W5 }}{\text { JAWA TENGAH }}$}} & \multirow{2}{*}{\multicolumn{2}{|c|}{$\begin{array}{c}\text { W6 } \\
\text { JAWA TIMUR }\end{array}$}} & \multirow{2}{*}{\multicolumn{2}{|c|}{$\frac{\text { W7 }}{\text { KALIMANTAN }}$}} & \multirow{2}{*}{\multicolumn{2}{|c|}{\begin{tabular}{|c|} 
W8 \\
KEPULAUAN RIAU \\
\end{tabular}}} & \multirow{2}{*}{\multicolumn{2}{|c|}{$\begin{array}{c}\text { W9 } \\
\text { SUMATERA BARAT }\end{array}$}} & \multirow{2}{*}{\multicolumn{2}{|c|}{\begin{tabular}{|c|} 
W10 \\
SUMATERA SELATAN
\end{tabular}}} & \multirow{2}{*}{\multicolumn{2}{|c|}{$\begin{array}{c}\text { W11 } \\
\text { SUMATERA UTARA }\end{array}$}} & \multirow{3}{*}{ Kapasitas } & \multirow{3}{*}{ Penugasan } & \multirow{3}{*}{ SISA } & \multirow{3}{*}{\begin{tabular}{|c|} 
TOTAL BIAYA \\
RIBUAN \\
\end{tabular}} \\
\hline & & & & & & & & & & & & & & & & & & & & & & & & & & & \\
\hline & & & RIBUAN & & RIBUAN & & RIBUAN & & RIBUAN & & RIBUAN & & RIBUAN & & RIBUAN & & RIBUAN & & RIBUAN & & RIBUAN & & RIBUAN & & & & \\
\hline $\mathrm{S1}$ & jakarta & 0 & $\mathrm{Rpo}$ & 0 & Rpo & 147 & \begin{tabular}{|l|} 
Rp $1,790,460$ \\
\end{tabular} & 50 & Rp2,849,000 & 0 & Rpo & 0 & $\mathrm{RpO}$ & 0 & Rpo & 0 & Rpo & 0 & Rpo & 0 & Rpo & 0 & Rpo & 247 & 197 & 50 & \begin{tabular}{|l|} 
Rp4 4639,460 \\
\end{tabular} \\
\hline S2 & medan & 0 & $\mathrm{Rpo}$ & 0 & $\mathrm{RpO}$ & 0 & Rpo & 0 & $\mathrm{RpO}$ & 0 & $\mathrm{RpO}$ & 0 & $\mathrm{RpO}$ & 0 & Rpo & 0 & Rpo & 1 & Rp53,872 & 0 & $\mathrm{RpO}$ & 6 & Rp52,200 & 30 & 7 & 23 & Rp106,072 \\
\hline S3 & tangerang & 0 & Rpo & 30 & Rp261,000 & 0 & Rpo & 12 & Rp502,800 & 0 & $\mathrm{RpO}$ & 0 & Rpo & 0 & $\mathrm{RpO}$ & 0 & Rpo & 0 & Rpo & 0 & Rpo & 0 & RpO & 42 & 42 & 0 & Rp 763,800 \\
\hline 54 & bandung & 0 & Rpo & 0 & Rpo & 0 & Rpo & 30 & Rp295,800 & 0 & Rpo & 0 & $\mathrm{RpO}$ & 0 & Rpo & 0 & Rpo & 0 & $\mathrm{RpO}$ & 0 & $\mathrm{RpO}$ & 0 & $\mathrm{RpO}$ & 30 & 30 & 0 & Rp295,800 \\
\hline S5 & semarang & 3 & Rp233,910 & 0 & Rpo & 0 & Rpo & 0 & $\mathrm{RpO}$ & 27 & Rp234,900 & 0 & $\mathrm{RpO}$ & 0 & Rpo & 0 & Rpo & 0 & Rpo & 0 & $\mathrm{RpO}$ & 0 & Rpo & 30 & 30 & 0 & Rp468,810 \\
\hline 56 & surabaya & 5 & Rp439,325 & 0 & Rpo & 0 & Rpo & 0 & $\mathrm{RpO}$ & 0 & $\mathrm{RpO}$ & 26 & Rp241,280 & 0 & $\mathrm{RpO}$ & 0 & Rpo & 0 & $\mathrm{RpO}$ & c & Rpo & 0 & $\mathrm{RpO}$ & 34 & 31 & 3 & Rp680,605 \\
\hline 57 & denpasar & 2 & Rp122,140 & 0 & Rpo & 0 & Rpo & 0 & Rpo & 0 & Rpo & 0 & $\begin{array}{ll}\mathrm{RpO} \\
\end{array}$ & 0 & Rpo & 0 & Rpo & 0 & Rpo & c & $\begin{array}{ll}\mathrm{RpO} \\
\end{array}$ & 0 & Rpo & 2 & 2 & 0 & Rp122,140 \\
\hline 58 & pontianak & 0 & Rpo & 0 & $\mathrm{RpO}$ & 0 & Rpo & 0 & $\mathrm{RpO}$ & 0 & Rpo & 0 & $\mathrm{RpO}$ & 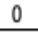 & Rpo & 0 & Rpo & 0 & $\mathrm{RpO}$ & 0 & $\mathrm{RpO}$ & 0 & $\mathrm{RpO}$ & 4 & 0 & 4 & \\
\hline 59 & balikpapan & 0 & Rpo & 0 & Rpo & 0 & Rpo & 0 & $\begin{array}{ll}\mathrm{RpO} \\
\end{array}$ & 0 & Rpo & 0 & $\begin{array}{ll}\text { Rpo } \\
\end{array}$ & 1 & Rp41,410 & 0 & Rpo & 0 & RpO & 0 & Rpo & 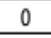 & Rpo & 4 & 1 & 3 & Rp41,410 \\
\hline 510 & batam & 0 & Rpo & 0 & Rpo & 0 & Rpo & 0 & $\begin{array}{ll}\mathrm{RpO} \\
\end{array}$ & 0 & Rpo & 0 & $\begin{array}{ll}\mathrm{RpO} \\
\end{array}$ & 0 & Rpo & 1 & $\mathrm{Rp} 50,250$ & 0 & Rpo & 0 & Rpo & 0 & $\begin{array}{ll}\mathrm{RpO} \\
\end{array}$ & 6 & 1 & 5 & $\operatorname{Rp} 50,250$ \\
\hline S11 & ambon & 0 & Rpo & 0 & Rpo & 0 & Rpo & 0 & $\mathrm{RpO}$ & 0 & Rpo & 0 & $\mathrm{RpO}$ & 0 & Rpo & 0 & Rpo & 0 & Rpo & 0 & Rpo & 0 & $\mathrm{RpO}$ & 2 & 0 & 2 & \\
\hline S12 & banda aceh & 0 & Rpo & 0 & $\mathrm{RpO}$ & 0 & Rpo & 0 & Rpo & 0 & $\mathrm{RpO}$ & 0 & Rpo & 0 & Rpo & 0 & Rpo & 0 & Rpo & 0 & Rpo & 0 & Rpo & 2 & 0 & 2 & \\
\hline$S 13$ & pekanbaru & 0 & Rpo & 0 & Rpo & 0 & Rpo & 0 & $\mathrm{RpO}$ & 0 & $\mathrm{RpO}$ & 0 & $\mathrm{RpO}$ & 0 & Rpo & 0 & Rpo & 0 & RpO & 0 & Rpo & 0 & $\mathrm{RpO}$ & 4 & 0 & 4 & Кр \\
\hline S14 & makassar & 0 & Rpo & 0 & Rpo & 0 & Rpo & 0 & $\mathrm{RpO}$ & 0 & Rpo & 0 & $\mathrm{RpO}$ & 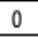 & Rpo & 0 & Rpo & 0 & Rpo & 0 & Rpo & 0 & $\mathrm{RpO}$ & 2 & 0 & 2 & \\
\hline S15 & palembang & 0 & Rpo & 0 & Rpo & 0 & Rpo & 0 & $\begin{array}{ll}\mathrm{RpO} \\
\end{array}$ & 0 & Rpo & 0 & $\mathrm{RpO}$ & 0 & Rpo & 0 & Rpo & 0 & Rpo & 1 & Rp39,910 & 0 & Rpo & 8 & 1 & 7 & Rp39,910 \\
\hline$S 16$ & lampung & 0 & Rpo & 0 & Rpo & 0 & Rpo & 0 & $\begin{array}{ll}\mathrm{Rp} 0 \\
\end{array}$ & 0 & Rp0 & 0 & Rpo & 0 & Rpo & 0 & Rpo & 0 & Rpo & 0 & Rpo & 0 & Rpo & 6 & 0 & 6 & \\
\hline$\$ 17$ & banjarmasin & 2 & Rp175,238 & 0 & Rpo & 0 & Rpo & 0 & $\begin{array}{ll}\mathrm{RpO} \\
\end{array}$ & 0 & Rpo & 0 & $\begin{array}{ll}\mathrm{RpO} \\
\end{array}$ & 0 & Rpo & \begin{tabular}{|l} 
\\
\end{tabular} & Rpo & 0 & Rpo & 0 & Rpo & 0 & Rpo & 2 & 2 & 0 & Rp175,238 \\
\hline \multirow[t]{3}{*}{ S18 } & manado & 0 & Rpo & 0 & Rpo & 0 & Rpo & 0 & $\mathrm{RpO}$ & 0 & Rpo & 0 & Rpo & 0 & Rpo & 0 & Rpo & 0 & Rpo & 0 & Rpo & 0 & $\mathrm{RpO}$ & 2 & 0 & 2 & \\
\hline & KAPASITAS & 12 & & 30 & & 147 & & 92 & & 27 & & 26 & & 1 & & 1 & & 1 & & 1 & & 6 & & 457 & 344 & 113 & Rp 7,383,495 \\
\hline & PENGGUNA & 12 & Rp970,613 & 30 & Rp261,000 & 147 & \begin{tabular}{|l|} 
Rp1 $1,790,460$ \\
\end{tabular} & 92 & Rp3,647,600 & 27 & Rp234,900 & 26 & Rp241,280 & 1 & Rp41,410 & 1 & $\mathrm{Rp} 50,250$ & 1 & Rp53,872 & 1 & Rp39,910 & 6 & Rp52,200 & & & & \\
\hline
\end{tabular}

ISSN 2614-283X (online) / ISSN 2620-6757 (print)

Copyright @ 2017, Politeknik Keuangan Negara STAN. All Rights Reserved 
Vol. 4, No. 1, 2020

Lampiran I

TABEL PENUGASAN AUDIT DAN BIAYA PERJALANAN DINAS

SIMULASI ZONING

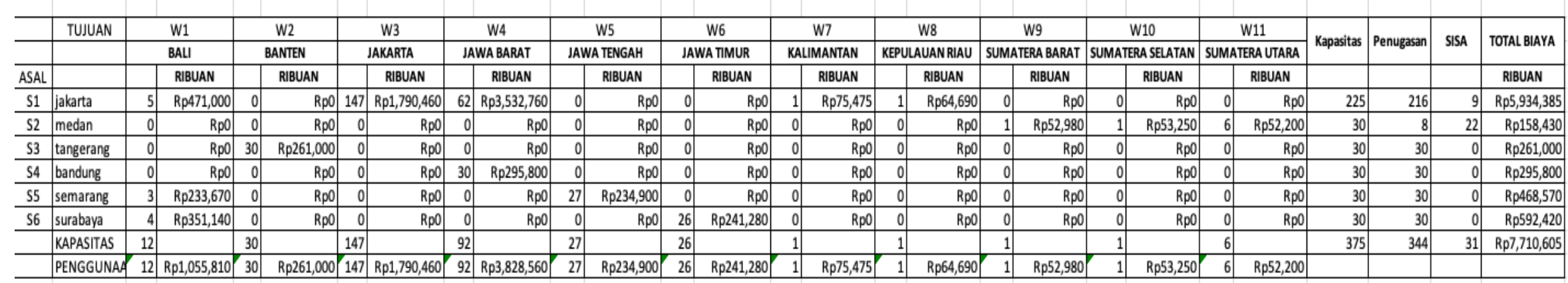

ISSN 2614-283X (online) / ISSN 2620-6757 (print)

Copyright @ 2017, Politeknik Keuangan Negara STAN. All Rights Reserved 